\title{
Bond Strength of a Composite Resin to an Adhesive Luting Cement
}

\author{
Taciana Marco Ferraz CANEPPELE \\ Lucas V. ZOGHEIB \\ Isabela GOMES \\ Andressa S. KUWANA \\ Clóvis PAGANI \\ Department of Restorative Dentistry, São José dos Campos Dental School, \\ São Paulo State University, São José dos Campos, SP, Brazil
}

\begin{abstract}
This study evaluated the influence of surface treatment on the shear bond strength of a composite resin (CR), previously submitted to the application of a temporary cement (TC), to an adhesive luting cement. Eight-four CR cylinders $(5 \mathrm{~mm}$ diameter and $3 \mathrm{~mm}$ high) were fabricated and embedded in acrylic resin. The sets were divided into 6 groups (G1 to G6) (n=12). Groups 2 to 6 received a coat of TC. After 24 h, TC was removed and the CR surfaces received the following treatments: G2: ethanol; G3: rotary brush and pumice; G4: air-abrasion; G5: air-abrasion and adhesive system; G6: air-abrasion, acid etching and adhesive system. G1 (control) did not receive TC or any surface treatment. The sets were adapted to a matrix and received an increment of an adhesive luting cement. The specimens were subjected to the shear bond strength test. ANOVA and Tukey's tests showed that G3 (8.53 MPa) and G4 (8.63 $\mathrm{MPa}$ ) differed significantly $(\mathrm{p}=0.001)$ from G1 $(13.34 \mathrm{MPa})$. The highest mean shear bond strength values were found in G5 (14.78 $\mathrm{MPa}$ ) and G6 (15.86 MPa). Air-abrasion of CR surface associated with an adhesive system provided an effective bond of the CR to the adhesive luting cement, regardless the pre-treatment with the phosphoric acid.
\end{abstract}

Key Words: composite resin, resin cement, bond strength, dental air abrasion.

\section{INTRODUCTION}

The advance of adhesive techniques in Dentistry has increased the use of composite resins. Currently, this material is widely used in direct and indirect restorative procedures. Composite resin can be used to make cores on prefabricated posts (1), as a cavity filling material (2), as a dentin sealing material in the resin-coating technique, (3) and also as a luting agent (4).

It is known that during light curing of resin materials, the presence of oxygen does not allow the complete polymerization of the surface, which favors the bonding of new increments of chemically similar materials (5).

In adhesive cementation, there is an interaction between the luting cement and the non-polymerized surface layer of the adhesive applied to the dental substrate (6). In addition, in situations when the tooth is rebuilt with a composite core, an interaction between this material and the luting cement should occur. Although both materials are chemically similar, the suitable bond achieved by the non-polymerized surface layer is harmed because in the composite resin core, the surface is completely polymerized and contaminated by saliva and temporary cement residues (7).

Several techniques have been suggested for removing temporary cement (8-10). Schwartz et al. (10) reported that cleaning with pumice is effective, while, Paul et al. (11) found that pumice is inefficient for surface cleaning.

The bond between resin materials has been extensively investigated $(7,12,13)$. Nevertheless, there is no consensus in the literature about which is the best surface treatment to achieve a good adhesion between contaminated polymerized resins and resin-based luting systems. Therefore, the aim of this study was to assess the influence of surface treatment on the shear bond strength of a composite resin, previously submitted to

Correspondence: Dra. Taciana Marco Ferraz Caneppele, Avenida Salmão, 663 - cj. 13/15, 12246-260 São José dos Campos, SP, Brasil. Tel./Fax: +55-12-3923-2300. email: tacileo@uol.com.br 
application of a temporary cement, and an adhesive luting cement. The null hypothesis was that there is no significant difference in shear bond strength between treatment protocols.

\section{MATERIAL AND METHODS}

Eighty-four cylindrical composite specimens (Esthet-X; Dentsply, Petrópolis, RJ, Brazil) were made using a silicon mold with inner diameter of $5 \mathrm{~mm}$ and 2 $\mathrm{mm}$ high. The resin was inserted in a single increment and a polyester strip was placed over the material. Light curing was done onto the polyester strip for $40 \mathrm{~s}$, using a halogen lamp (Curing Light XL 3000; $3 \mathrm{M}$ ESPE, St. Paul, MN, USA) with light intensity of $600 \mathrm{~mW} / \mathrm{cm}^{2}$. The cylinders were removed from the mold and the bases of the cylinders were light cured for $40 \mathrm{~s}$.

The cylinders were embedded in acrylic resin (Jet Clássico, São Paulo, SP, Brazil) using a silicon mold measuring $30 \times 20 \times 7 \mathrm{~mm}$, taking care to leave one of their flat surfaces exposed. For finishing and polishing this surface, the resin blocks were taken to a DP-10 polishing machine (Struers; Ballerup, Copenhagen, Denmark) and subjected to a sequence of 80-, 180- and 400-grit silicon carbide ( $\mathrm{SiC})$ abrasive papers under running water for $30 \mathrm{~s}$. Next, the blocks were washed with air-water spray and dried with air jets. The specimens were then divided into 6 groups ( $\mathrm{n}=12$ ). G1 (control) did not receive temporary cement or any surface treatment. The composite resin specimens in Groups 2 to 6 received a coat of Temp Bond NE (Kerr Corp., Orange, CA, USA) temporary cement onto its entire surface. The cement was mixed according to the manufacturer's instructions. After waiting $6 \mathrm{~min}$ for cement setting, the cylinders were stored at $37^{\circ} \mathrm{C}$ in relative humidity for $24 \mathrm{~h}$. After this period, the temporary cement was removed with a dentin excavator, followed by rinsing with an air-water spray and air drying. After temporary cement removal, the composite resin cylinders received the following surface treatments: G2 - Cleaning with a cotton pellet containing ethanol for $10 \mathrm{~s}$ and drying with jets of compressed air (3); G3 - Rotary brush with pumice applied for $15 \mathrm{~s}$, followed by washing with air-water spray for $30 \mathrm{~s}$ and drying with jets of compressed air (8); G4 - Air-abrasion with $50 \mu \mathrm{m}$ grain alumina (Microetcher, San Ramon, CA, USA) for $10 \mathrm{~s}$ (9) followed by washing with air-water spray for $30 \mathrm{~s}$ and drying with compressed air streams; G5 - Air-abrasion with $50 \mu \mathrm{m}$ grain alumina for $10 \mathrm{~s}$ (9), followed by rinsing with air-water spray for $30 \mathrm{~s}$, drying with compressed air streams, coating with a layer of adhesive system (ScotchBond Multi Purpose; 3M ESPE) using a disposable microbrush tip (Microbrush Corp.; Grafton, WI, USA), and photoactivation for $20 \mathrm{~s}$ (Curing Light XL 3000; 3M ESPE); G6 - Air-abrasion with $50 \mu \mathrm{m}$ grain alumina for $10 \mathrm{~s}$, followed by rinsing with air-water spray for $30 \mathrm{~s}$, drying with compressed air streams, etching with $37 \%$ phosphoric acid (10), and coating with a layer of adhesive system applied and photoactivated as described above.

All blocks were then adapted to a polytetrafluorethylene matrix ( $3 \mathrm{~mm}$ diameter and $2 \mathrm{~mm}$ high), and the composite resin surfaces received a $2 \mathrm{~mm}$ increment of Panavia $F$ adhesive luting cement (Kuraray, Kurashiki City, Japan), which was photoactivated for 40 $\mathrm{s}$, according to the manufacturer's recommendations.

The test specimens were stored in distilled water at $37^{\circ} \mathrm{C}$ for $24 \mathrm{~h}$, and taken to a universal test machine (DL-1000; Equipamentos e Sistemas de Ensaio Ltda., São José dos Pinhais, PR, Brazil). A shear force was applied with a load cell of $100 \mathrm{kgf}$ in the composite resin/ cement interface with a chisel-shaped rod attached to the universal testing machine at a crosshead speed of 1 $\mathrm{mm} / \mathrm{min}$ until bonding failure. This chisel had a $3-\mathrm{mm}$ diameter saddle-shaped end (Fig. 1). The load at fracture was divided by the crossectional area of the bonding surface $\left(7.07 \mathrm{~mm}^{2}\right)$ to calculate the nominal stress across the specimen at fracture in MPa. All fractured surfaces were examined with a stereomicroscope (Stemi 2000C; ZEISS, Petrópolis, RJ, Brazil), at $\times 25$ magnification to determine the failure mode (adhesive or cohesive).

Data obtained were analyzed by ANOVA and Tukey's multiple-comparison test at a 5\% significance level using Minitab statistical software, version 14.12, 2004 (Minitab Inc., State College, PA, USA).

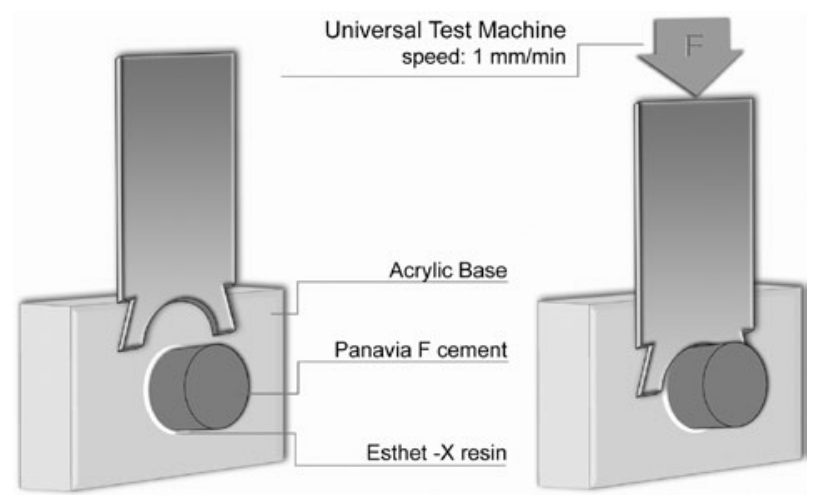

Figure 1. Diagrammatic illustration showing the shear test. 


\section{RESULTS}

There were significant differences among the groups with different surface treatments $(\mathrm{f}=9.71$; $\mathrm{p}=0.000$ ). $\mathrm{G} 5$ and G6 presented the highest shear bond strength values and did not differ significantly from G1. G2 did not differ significantly from G1 either (Table 1).

Table 2 shows the failure mode distribution in the groups. G3 presented $100 \%$ of adhesive failures while G5 and G6 presented 100\% of cohesive failures. All cohesive failures were in the composite resin Esthet-X.

\section{DISCUSSION}

strength values between the composite resin and luting cement were observed in G3 (rotary brush + pumice) and G4 (air-abrasion with $50 \mu \mathrm{m}$ grain alumina), being significantly lower than the control group (G1), which was not contaminated by temporary cement. Thus, these two treatments were not considered efficient for surface cleaning. With regard to treatment with pumice, Paul and Scharer (11) reported its inefficiency in dentin cleaning after contamination with temporary cement. However, Schwartz et al. (10) found that the rotary brush associated with pumice was effective.

Although air-abrasion with $50 \mu \mathrm{m}$ grain alumina
Under clinical conditions, contamination by temporary cement can influence the shear bond strength between resinous materials. Thus, effective surface cleaning is necessary. This study assessed the influence of surface treatment of a composite resin, previously submitted to application of a temporary cement, on the shear bond strength of an adhesive luting cement.

In this study, the methodology used to assess bond strength was the shear test as previously used $(7,14)$. It is an acknowledged methodology and is easy to perform. Different devices can be used to perform the shear strength test, such as chisel systems (straight chisel, saddle-shaped chisel), stainless steel tape and piston (15). In the present study, the option was to use a saddle-shaped chisel (Fig. 1) because there was a larger area of contact between the chisel and the specimen during the test, thus with better distribution of forces. One disadvantage of the shear test is the size of the bond area.

According to Della Bona et al. (16), the larger the bond area, the greater the possibility of formation bubbles and porosities, which will affect the adhesion. In this study, the bond area was $7.07 \mathrm{~mm}^{2}$, whereas microtensile studies have areas close to $1 \mathrm{~mm}^{2}$. The results of this study showed that the lowest shear bond
Table 2. Failure mode distribution in the groups.

\begin{tabular}{lcc}
\hline Composite surface treatment & $\begin{array}{c}\text { Adhesive } \\
(\%)\end{array}$ & $\begin{array}{c}\text { Cohesive } \\
(\%)\end{array}$ \\
\hline No treatment (G1) & 75 & 25 \\
Ethanol (G2) & 58.3 & 41.7 \\
Rotary brush + pumice (G3) & 100 & -- \\
Air-abrasion (G4) & 83.3 & 16.7 \\
Air-abrasion + adhesive (G5) & -- & 100 \\
$\begin{array}{l}\text { Air-abrasion + acid etching + } \\
\text { adhesive (G6) }\end{array}$ & -- & 100 \\
\hline
\end{tabular}


(G4) produced low shear bond strength values, its association with the adhesive system (G5 and G6) increased significantly the bond strength to the adhesive luting cement. According to Padipatvuthikul and Mair (14), there are two explanations for the action of adhesive system in these cases. Firstly, the airborne particle abraded surface contains micro-defects that can be penetrated by the adhesive fluid, resulting in micromechanical retention. Secondly, the solvents present in the adhesive systems may cause an alteration in the surface layer, allowing the monomer of the resinous cement to react with the non converted vinyl groups $(-\mathrm{C}=\mathrm{C})$ at the subsurface.

As regards the effectiveness of phosphoric acid application before adhesive application, although there was higher shear bond strength in this group (G6), it did not differ significantly from the group without acid application (G5). The action of phosphoric acid at the surface of the composite resin is a cleansing action. With the previous use of air abrasion, this action may not have caused significant effects on the bond strength.

Surface cleaning with ethanol (G3) was shown to be a simple and effective technique, as it did not differ significantly from the control group (G1), although it had lower values than groups G5 and G6. This technique is recommended by some authors $(17,18)$ in the resin coating technique, in which dentin sealing is done soon after preparation, before the stages of molding and making temporary restorations. Ethanol is a solvent of organic material and promote surface cleaning, which facilitates the bond between composite resin and resinous cement (18).

With regard to the bond failures, it was observed that in the groups that presented higher shear bond strength (G5 and G6), all tested specimens had cohesive failures in the composite resin. Della Bona et al. (19) and Della Bona and Van Noort (16) discussed this problem and concluded that shear tests measure the resistance of the adjacent composite rather than the resistance to bonding. However, the adjacent resin is only going to fracture if the shear bond strength at the interface is high. In this study, the fractures occurred at the bond interface in the groups in which the shear bond strength presented lower values (Table 2). In the groups with the highest shear bond strength values (G5 and G6), only cohesive failures occurred, demonstrating that the interface had a good resistance, fracturing the base composite.

Within the limitations of this study, it was concluded that ethanol, air-abrasion associated with adhesive system and air-abrasion associated with the phosphoric acid were effective for cleaning the surface of composite resin from temporary cement residues, promoting an effective bond of composite to an adhesive luting cement.

\section{RESUMO}

A influência do tratamento de superfície sobre a resistência adesiva entre uma resina composta (RC), previamente submetida à aplicação de um cimento temporário (CT), e um cimento resinoso foi avaliada. Oitenta e quatro cilindros de RC ( $5 \mathrm{~mm}$ de diâmetro e $3 \mathrm{~mm}$ de altura) foram confeccionados e incluídos em resina acrílica. Os conjuntos foram divididos em 6 grupos (G1 a G6) $(\mathrm{n}=12)$. Os grupos de 2 a 6 receberam uma camada do CT. Após $24 \mathrm{~h}$, o CT foi removido e as superfícies de $\mathrm{RC}$ receberam os seguintes tratamentos: G2: limpeza com etanol; G3: limpeza com escova rotatória e pedra pomes; G4: jateamento ; G5: jateamento e aplicação de adesivo; G6: jateamento, condicionamento ácido e adesivo. O G1(controle) não recebeu CT ou nenhum tratamento de superfície. Os conjuntos foram adaptados à matriz e receberam incremento de cimento resinoso. Os corpos de prova foram submetidos ao ensaio de cisalhamento. Os testes ANOVA e Tukey $(\mathrm{p}=0,001)$, demonstraram que os grupos G3 (8,53 MPa) e G4 (8,63 MPa) diferiram estatisticamente do grupo G1 (13,34 $\mathrm{MPa}$ ). As maiores valores médios de resistência ao cisalhamento foram encontradas nos grupos G5 (14,78 MPa) e G6 (15,86 MPa). $\mathrm{O}$ jateamento da superfície da resina composta associado a um sistema adesivo, independente do pré-tratamento com o ácido fosfórico, proporcionou uma efetiva união ao cimento resinoso.

\section{REFERENCES}

1. Schwartz RS, Robbins JW. Post placement and restoration of endodontically treated teeth: a literature review. J Endod 2004;30:289-301.

2. Monteiro PM, Manso MC, Gavinha S, Melo P. Two-year clinical evaluation of packable and nanostructured resin-based composites placed with two techniques. J Am Dent Assoc 2010;141:319-329.

3. Duarte S, Jr., de Freitas CR, Saad JR, Sadan A. The effect of immediate dentin sealing on the marginal adaptation and bond strengths of total-etch and self-etch adhesives. J Prosthet Dent 2009;102:1-9.

4. Rosenstiel SF, Land MF, Crispin BJ. Dental luting agents: A review of the current literature. J Prosthet Dent 1998;80:280-301.

5. Shawkat ES, Shortall AC, Addison O, Palin WM. Oxygen inhibition and incremental layer bond strengths of resin composites. Dent Mater 2009;25:1338-1346.

6. Li J. Effects of surface properties on bond strength between layers of newly cured dental composites. J Oral Rehabil 1997;24:358360 .

7. Tezvergil A, Lassila LV, Vallittu PK. Composite-composite repair bond strength: effect of different adhesion primers. J Dent 2003;31:521-525.

8. Mosharraf R, Soleimani B, Sanaee-Nasab M. A comparison of two methods of removing zinc oxide-eugenol provisional cement residue from the internal surface of cast restorations. J Contemp Dent Pract 2009;10:27-34. 
9. Chaiyabutr Y, Kois JC. The effects of tooth preparation cleansing protocols on the bond strength of self-adhesive resin luting cement to contaminated dentin. Oper Dent 2008;33:556-563.

10. Schwartz R, Davis R, Hilton TJ. Effect of temporary cements on the bond strength of a resin cement. Am J Dent 1992;5:147-150.

11. Paul SJ, Scharer P. Effect of provisional cements on the bond strength of various adhesive bonding systems on dentine. J Oral Rehabil 1997;24:8-14.

12. Kupiec KA, Barkmeier WW. Laboratory evaluation of surface treatments for composite repair. Oper Dent 1996;21:59-62.

13. Brosh T, Pilo R, Bichacho N, Blutstein R. Effect of combinations of surface treatments and bonding agents on the bond strength of repaired composites. J Prosthet Dent 1997;77:122-126.

14. Padipatvuthikul P, Mair LH. Bonding of composite to water aged composite with surface treatments. Dent Mater 2007;23:519-525.

15. Sinhoreti MA, Consani S, De Goes MF, Sobrinho LC, Knowles JC.
Influence of loading types on the shear strength of the dentin-resin interface bonding. J Mater Sci Mater Med 2001;12:39-44.

16. Della Bona A, van Noort R. Shear vs. tensile bond strength of resin composite bonded to ceramic. J Dent Res 1995;74:1591-1596.

17. Nikaido T, Nakaoki Y, Ogata M, Foxton R, Tagami J. The resincoating technique. Effect of a single-step bonding system on dentin bond strengths. J Adhes Dent 2003;5:293-300.

18. Jayasooriya PR, Pereira PN, Nikaido T, Tagami J. Efficacy of a resin coating on bond strengths of resin cement to dentin. J Esthet Restor Dent 2003;15:105-113; discussion 113.

19. Della Bona A, Anusavice KJ, Mecholsky JJ, Jr. Failure analysis of resin composite bonded to ceramic. Dent Mater 2003;19:693-699.

Accepted September 9, 2010 